\title{
BEYOND THE RESTRICTIVE CONSENSUS: ELECTIONS IN MEXICO (1809-1847)
}

\author{
José Antonio Aguilar Rivera
}

\begin{abstract}
RESUMO
Este ensayo analiza los experimentos con el sistema representativo en la Nueva España primero y en México después. Las elecciones que se realizaron todavía bajo el dominio español dieron cuenta de las dinámicas políticas de esta forma de gobierno, como la amplia participación política. Se estudian las elecciones durante las primeras décadas de la independencia, hasta el comienzo de la guerra con Estados Unidos, y se encuentra que a pesar de que para los años treinta del siglo XIX había una consenso creciente entre las elites sobre la deseabilidad de excluir a las clases populares de las elecciones fue imposible mantener las exclusiones censitarias durante mucho tiempo. Ninguna de las facciones fue capaz de abstenerse de acudir a las "clases peligrosas". El capitulo da cuenta de las razones de esta imposibilidad. Existen diversas hipótesis para explicar este patrón. Se aduce que en un principio la incipiente apertura de la franquicia obedeció a la competencia entre facciones antagónicas. Sin embargo, a finales de los años 1820 la movilización popular ocasionó desórdenes sociales, como la destrucción del mercado del Parián, lo que ocasionó que empezara a ser vista como disfuncional por las élites. A mediados de los años 1830 las clases dirigentes decidieron abstenerse de echar mano de las clases populares en las luchas electorales. Sin embargo este acuerdo no duró, se propone, debido a que los conservadores abandonaron la idea del sufragio censitario y los liberales, debido a sus triunfos electorales, renovaron su insistencia en mantener una amplia franquicia.
\end{abstract}

PALABRAS-LLAVE: representative government; XIX th century Mexico; voting rights; electoral practices; political mobilization.

\section{INTRODUCTION}

\begin{abstract}
"Deseamos que el gobierno tenga la fuerza necesaria para cumplir con sus deberes [...]. Estamos decididos contra la federación; contra el sistema representativo por el orden de elecciones que se ha seguido hasta ahora; contra los ayuntamientos electivos y contra todo lo que se llama elección popular, mientras no descanse sobre otras bases" (Alamán, 1986).
\end{abstract}

In 1815 an elderly John Adams wrote to James Lloyd: "The people of South America are the most ignorant, the most bigoted, the most superstitious of all the Roman Catholics in Christendom [...]. No Catholics on earth were so abjectly devoted to their priests, as blindly superstitious as

\footnotetext{
1 I wish to thank Roberto Mostajo for his assistance in researching and writing this paper. I would also like to thank Alfredo Ávila, Eduardo Posada, Samuel Valenzuela and Jorge E. Rodríguez for their detailed comments and suggestions.
}

themselves, and these priests had the powers and apparatus of the Inquisition to seize every suspected person and suppress every rising motion. Was it probable, was it possible, that such a plan as [Francisco] Miranda's, of a free government, and a confederation of free governments, should be introduced and established among' such a people, over that vast continent, or any part of it? It appeared to me more extravagant than the schemes of Condorcet and Brissot to establish a democracy in France, schemes which had always appeared to me as absurd as similar plans would be to establish 
democracies among the birds, beasts, and fishes (ADAMS, 1856, p. 143-145)2.

Yet, by the time Adams wrote these often quoted lines, Spanish America had already begun to experiment with the institutions of representative government and highly competitive elections had taken place in New Spain in 1812. It is indeed an irony that we know as much, if not more, about elections conducted in New Spain under colonial rule from 1809 to 1821 than about some periods during the national $\mathrm{era}^{3}$. Elections were very frequent events in Mexico. A yet to be determined number (probably ranging in the hundreds) of electoral contests took place at the national, state and municipal levels during the 19th century. Elections were perceived by political elites as key to achieving political results, thus tinkering and experimenting with electoral legislation was very common. No less than forty-six different statues and laws regulating elections were enacted during the $19^{\text {th }}$ Century ${ }^{4}$. If political contest were, as early scholars thought, decided mainly by military caudillos, Santa Anna-style, then why was such an enormous amount of energy placed on reforming electoral laws for a very long time ${ }^{5}$ ?

It is easy to miss the significance of regular institutions during an age of political turmoil and

2 Letter to James Lloyd, March 27, 1815, The key reason for Adams' skepticism regarding the possibilities of democracy in South America were the deleterious consequences of religious intolerance.

3 The Cádiz Constitution was in force in New Spain very few years: 1812-1814, and 1820-1821.

4 For a compendium of electoral laws in Mexico during the $19^{\text {th }}$ Century, see Orozco (1978)

5 During the colonial period (1812-1821), there were six statues, Independence and First Empire, (1821-1823) there were two, during the First Federal Republic (1824-1835) there were four, during the Central Republic (1835-1846) there were 11 laws, during the Second Federal Republic (1847-1854) there were 10 statues, during the Ayutla period (1854-1857) there were two laws, during the formation of the Liberal Republic and until the fall of the Second Empire (1857-1867) there were four laws, during the Resto red Republic (1867-1876) there were eight laws and during the rule of general Porfirio Díaz in the 19th century (1876-1900) there was only one law enacted, the law of December 16 1882, "Decreto que reforma la ley electoral de 12 de febrero de 1857 ". This pattern needs to be explained. instability. Yet, as Michael Costeloe remarked a decade ago, "during the so-called age of Santa Anna or three decades from Iturbide to Juárez there were only four brief occasions on which the executive branch enjoyed unrestricted dominance. Indeed, one feature of the period, which has been neither analyzed nor appreciated, is the role of the legislative power, particularly the National Congress that from 1822 onwards was summoned and met, with one or two gaps, more or less continuously. In 34 years, between 1821 and 1855, 22 congresses convened (SORDO, 1994, p. 142-143) ${ }^{6}$. Thus, elections took place quite often although they did not always follow a regular calendar. The forty-six electoral laws are, perhaps, explained by the fact that many times losers decided to reform the mechanisms for conducting elections instead of making war. The military certainly dominated the route to executive authority at both national and state levels through revolt, but the generals, including and perhaps above all Santa Anna, were singularly unable to control the National Congress which was always largely composed of popularly elected civilians" (COSTELOE, 1986, p. 258).

The absence of a well-documented history of elections in Mexico is to be noted, particularly at a time when finally the country has become a functioning democracy. Perhaps, the lack of interest in the electoral processes of the 19th century is due to the belief that caudillismo and political chaos rendered elections meaningless. Also, for a long time elections - past and present - were seen by some scholars as mere manifestations of "formal democracy". For example, in 1985 Gustavo Emmerich described the "electoral regimes" of the $19^{\text {th }}$ Century as an affair of the "dominant classes" (EMMERICH, 1985, p. 62). However, very little research has been conducted to support this claim. Empirical studies at both the national and local level are missing for key elections during the period. A few recent accounts of electoral history go beyond these limitations (see, for example, VARELA ORTEGA \& MEDINA PEÑA (2000)).

\footnotetext{
6 Note that if congress was renewed every two years (as provided by the 1824 Constitution) and a normal calendar had been observed for the period, there would have been 17 congresses elected between 1821 and 1855 . Yet, there were five more than expected.
} 
While the period 1867-1910 has received some attention from past and present scholars, our knowledge of elections between 1824 and 1857 is patchy at best. The period $1808-1824$, which covers the Cádiz experiment in New Spain and the founding of Mexico has received continued attention. The 1946 seminal work of Nettie Lee Benson on the 1812 Mexico City election provided a framework for the study of elections in Mexico (Benson, 1946; 1955; 2004). More recently, Virginia Guedea has studied the same period as well as the electoral processes of the insurgents (GUEDEA, 1991a; 1991b; 2001). The latest account of the creation of representative government in the early period is Alfredo Avilá's En nombre de la nación (AVILA, 1999). Benson's insight that the diputaciones provinciales created by the Cádiz charter were key to the developing of federalism in Mexico was followed many decades later by the finding that political fragmentation and instability was also due to the establishment of ayuntamientos constitucionales (constitutional townships) provided by the same constitution. Antonio Annino has extensively developed this line of inquiry (ANNINO, 1995; 1996; ORTÍZ \& SERRANO, 2007). Lately, Spanish liberalism has also been revisited as well as the relevance of the political crisis of the Spanish Monarchy (CHUST, 1999; RODRÍGUEZ, 2005a; 2008; BREÑA, 2006). The local dynamics of elections have also been researched in some regions, particularly Oaxaca (BELLINGERI, 1995; ESCOBAR, 1996; GUARDINO, 1998; 2003; 2007; CASTILLO, 2003; RODRÍGUEZ, 2005b; SERRANO, 2007).

Some studies have explored the relation between elections and popular mobilization (DI TELLA, 1994; WARREN, 1996; 2001; AVILA, 2004). The dynamics of political disintegration and the role played by electoral processes have also been explored as part of a broader account of the period (COSTELOE, 1989, p. 257-275; 1996; 2000). The period known as the "Restored Republic" (1867- 1876), when the Liberals finally defeated their Conservative opponents and imposed the 1857 liberal constitution, is better known. Early scholarship, epitomized by historian Daniel Cosío Villegas stressed the democratic character of the period. Cosío believed that the Restored Republic was an era of unparalleled freedoms (VILLEGAS, 1953; 1957, p. 123-150). However, more recent scholarship is quite critical of the period. According to Laurens Ballard Perry, elections were subject to constant manipulation by local and national political leaders. Whenever the President obtained congressional authorization to resolve political conflicts in the states, the use of federal intervention and emergency powers was seldom neutral. Juárez, for instance, ignored requests for federal intervention made by factional enemies, even when Congress ordered the national government to provide aid. At the same time, he supported his local allies by decreeing states of siege to allow electoral manipulation. These resources allowed the executive to obtain the selection of sympathetic electors, conduct electoral fraud, establish political alliances and exercise other forms of influence (PERRY, 1978). There are also some new studies of elections, factional struggles and the press during the Restored Republic (PALTI, 2003). The role played by electoral laws, particularly by the initial no re-election law, in the states during the Porfirio Díaz (1876-1910) era has been explored by scholars (CARMAGNANI, 1986; 1989; 1993; FALCÓN, 1988). As noted, the early republic has received less attention. Thus this paper centers on that period.

\section{THE ESTABLISHMENT OF REPRESENTA- TIVE GOVERNMENT IN NEW SPAIN 1812 1821}

The case for the impact of the years 1808 1810 in Spain and America has been made by Francois-Xavier Guerra (1980; 1992). In considering the transition from colonial rule to independence in New Spain there were three lasting lessons of the early establishment of representative institutions. First, elections had the potential of mobilizing popular participation from all quarters of society, secondly the authorities organizing the elections could lose them and thirdly the modes of organizing elections, particularly the indirect system and voter registration would prove to be enduring.

The first elections in New Spain preceded the 1812 Constitution. As a result of the invasion of Spain by French troops, a Junta Central was created in 1809 to represent all the Spanish Monarchy, including the American colonies. Elections of representatives to the Junta Central were held throughout the Spanish world during the year. Each province of Spain had two deputies to the Junta Central whereas the nine American kingdoms were allocated one each. 
The Junta Central decreed on January 1, 1810 that elections be held for Cortes. In Europe, each provincial junta and each city entitled to representation in previous Cortes would select a deputy. Also, a deputy was to be elected for every 50000 souls (RODRÍGUEZ, 2008, p. 105) ${ }^{7}$. The Junta dissolved and appointed a Council of Regency, which approved a different electoral process for America. Unlike the Spanish deputies, American deputies carried instructions from their provinces. Elections took place in New Spain starting in June 1810. One point must be mentioned. While the use of lots in the 1809 Spanish elections has not received much attention, it is significant from the standpoint of the history of representative government. Indeed, in the republican tradition lots were frequently used but disappeared at the end of the 18th century in the Italian city-states. Remarkably, the 1810 Spanish American elections were the last instance of lots used in the western world. Guerra asserts that selection by lot was not a republican, but rather a traditional practice. A way to quell factionalism and also a means to provide for divine intervention (GUERRA, 1992, p. 192). Yet, this issue deserves further investigation.

The Cortes promulgated the Constitution of the Spanish Monarchy on March 19, 1812 and it was sworn in Mexico City on September 30 of the same year. The constitution enfranchised all men, except those of African ancestry, vagrants, criminals, debtors, and domestic servants ${ }^{8}$. Yet, the Cádiz constitution firmly established what Manin calls the "principle of distinction". Representatives were to be different, and superior, to electors. The constitution provided that deputies should have a rent from personal property (Art. 92). Even if Art. 93 suspended this provision until future Cortes determined that the time had come to put it into effect, it is clear that the principle of distinction was in place (GARCÍA, 1978, p. 8).

On May 23, 1812 the Cortes issued a decree setting down the instructions for the first elections. In regard to New Spain, it provided

\footnotetext{
7 According to Rodríguez, those elections were based "on the municipal elections of diputados del común $y$ sindicos personeros introduced by Carlos III in the municipal reforms of 1766" (RODRÍGUEZ, 2008, p. 105).

8 Spaniards of African descent could become citizens by means of "virtue and merit" (Art. 22).
}

that a meeting of officials should be held in Mexico City prior to elections. The province of Mexico was to elect fourteen deputies and four alternates to the Cortes and one deputy and one alternate to the provincial deputation. The parish elections in Mexico City were set for November 29,1812 . The provincial electors of the provinces of Mexico were to meet in Mexico City on February 1, 1813.

Acording to Benson electoral provisions "were observed in the elections held in Mexico City on November 29, 1812. Not one judge reported unruliness or disorderly conduct on the part of the electorate during the proceedings. On the contrary, they unanimously stated that the parish meetings were executed in the midst of the greatest tranquillity and order" (BENSON, 1946). All those elected were from well-known families of Mexico City. However all the electors were American-born or creoles. There were popular demonstrations of joy that lasted until the next morning (GUEDEA, 2001, p. 54-56). A few days after the municipal elections newspapers in Mexico City published critical accounts of the process (BENSON, 1946, p. 342) ${ }^{9}$. The daily complained that lists with the names of electors had been widely distributed beforehand. Also, persons not entitled to vote had participated. The Audiencia of Mexico complained to the Spanish Cortes in similar terms in November 1813. It seems that the cause of most of these allegations was that "not a single European Spaniard nor a single person who supported the Europeans was elected" (idem, p. 349). Those elected were not followers of the colonial government. Some were active sympathizers of the rebels. In response to this defeat the Viceroy suspended the second stage of the electoral process and launched an investigation on the manner the election had been conducted. Freedom of the press was suppressed. It was clear that both, the results of the election and the popular mobilization it produced alarmed the colonial authorities.

The November 1812 election was modern in many ways. There were two well organized competing parties: the American-born creoles and the Europeans. Both followed the same electoral tactics of distributing lists of candidates to voters

9 "Sobre el nombramiento de elecciones municipales", $E l$ amigo de la patria quoted by Benson (1946, p. 342). 
beforehand. The factions employed individuals to distribute their lists among the people. Many voters did not know the names that were written on the lists they presented. However, the American faction proved much more effective at this game than its counterpart. It achieved an absolute victory. The distribution of lists was not illegal under the constitution although many actors viewed it as collusion. At the same time, popular participation was extensive and included individuals that according to the constitution could not vote, such as blacks, castes, domestic servants, vagrants and debtors (GUEDEA, 1991a, p. 2-15). These individuals wanted to participate in the election and in most cases were successful. Interestingly enough the losing side, although in power, did not subvert the process. While the electoral process was temporarily suspended it resumed eventually. In the end the electoral organizing of the Creoles prevailed and their faction won again the majority of electors. It is noteworthy that, according to Guerra, in that early election most inhabitants in the census of Mexico City were considered citizens (91\%). The franchise was nearly universal. Indeed, $93 \%$ of the male population were citizens (GUERRA, 1999).

The insurgents also carried out elections in the territories they held; first to elect a Junta Provincial and, later, a Congress. With some modifications the rebels followed the Cádiz model (GUEDEA, 1991b, p. 238). Those electoral experiences will no be discussed here (GUEDEA, 1991a; AVILA, 1999). In 1820 the Cádiz Constitution, which had been suspended by Fernando VII in 1814, was restored. The decree calling for elections for the Cortes was published in Mexico on June 3, 1820. A census of voters was made and elections for the Mexico province were held. As before 1814, the majority of those elected as first degree electors were Americans. Likewise, when the electors of partido convened to elect representatives on September 17, 1820 most seats were taken by creoles (AVILA, 1999, p. 190-195). Lucas Alamán, the future leader of the Conservative party, was elected as a representative from Guanajuato. In other provinces elections followed a similar pattern. The ayuntamientos constitucionales were restored as well as seven diputaciones provinciales. The elections of 1820-1821 were criticized for technical infractions, "but there were no events similar to the upheavals of 1812 . The most salient characteristic of both the Cortes and municipal council elections in 1820-1821 was the low voter tournout. Parish returns showed dramatic absenteeism" (WARREN, 1996, p. 40). Yet, on February 24, 1821 a Spanish army officer, Agustín de Iturbide, turned coats and sided with the insurgente leader, Vicente Guerrero, and declared independence from Spain. As Warren states, "the ideological debates and electoral experiences of the independence era strongly influenced the nation's development during the next generation. Moreover, elites and masses learned that elections could trigger general political ferment" (ibidem).

The legacy of the Cádiz constitution was twofold. On the one hand, the 1812 constitution provided the frame of an expanded franchise that would be very difficult to restrict in the new republic. On the other hand the Cádiz scheme of indirect elections proved to be long-lived. In Mexico, it lasted for many years until the 20th century. These legacies had significant political consequences. Three aspects are significant and survived until the 20th century. First, the procedure that allowed the polling tables to decide, without appeal, any complaint or issue during the voting. Second, the fact that secondary electors were not bound to obey primary voters and finally, the role of "jefes políticos". In Mexico Jefes politicos became key players after 1857 (VARELA ORTEGA \& MEDINA PEÑA, 2000, p. 209-213).

III. THE SHORT ROAD HOME: VOTING RIGHTS AND THE ELECTORAL SYSTEM

The right to vote did not develop in a straightforward manner in Mexico during the 19th century. As we have seen, the Cádiz Constitution awarded full citizenship to most men with "employment, trade or a known way of living" (Art. 25). While the 1812 Constitution did not provide for universal male suffrage (domestic servants, descendants of blacks and castes were excluded), the electoral procedures permitted a wide interpretation of the law ${ }^{10}$. Once independence was achieved suffrage was granted

10 The articles on citizenship were strikingly vague. Citizens were defined as those who "have their origin in the Spanish dominions of both hemispheres" and were settled in any village. Since there was no voter's list and 
to citizens over 18 years of age of all classes and castes, even foreigners. The November 17, 1821 "Convocatoria a Cortes" to a constituent Congress also broadened the franchise by eliminating racial requirements for citizenship (GARCÍA, 1978, p. 29; PANI, 2003, p. 97-100). Later, when the republic was established, the 1824 federal constitution left the determination of who could vote to the state legislatures (AGUILAR RIVERA, 2000, p. 156-157). However, we know that the first state constitutions (1824-1828) defined citizens as male, ideally pater familias. Nine states awarded citizenship to married men even if they were under the set age (PANI, 2003, p. 65-113). Men required a known address and a known mode of living. Many state charters excluded morally of physically unfit individuals: convicted felons, debtors, drunkards. Eleven states denied citizenship to domestic servants. Only three states, Mexico, Occidente and Querétaro, deprived the clergy of their political rights. Most states set reading and writing as a condition for voters and candidates but postponed enforcement until a time (ranging between 1835 and 1850) when enlightenment was widely distributed in the land. As Erika Pani asserts, some states suspended political rights to "ungrateful children" to their parents, and to husbands whom left their wives and to professional gamblers. Vagrants and persons who used to wander "shamefully naked" also were excluded in some places. In contrast, only six states punished selling or buying votes with the suspension of political rights. Two states required citizens to enroll in the militia and only one demanded citizens to register in the municipal census. Remarkably, only the state of Nuevo León established that in "due time" Congress would establish a minimum tax amount to determine eligibility to full citizenship.

This is surprising since in the 1823-1824 constituent Congress deputies were generally in

the vecinos at the polling table were the ones who determined who could vote the result was virtual universal male suffrage. From the records of the 1812-1814 elections we can see that few voters were turned down at the polling tables. Meanwhile, as we have seen a standard complaint of that period was that ineligible people voted at the elections. Note however, that in theory this procedure could have worked the other way around, restricting suffrage. favor of establishing a property condition for voters. A 1000 pesos amount was proposed by the commission in the draft of the constitution. Yet, two objections were put forth. First, as in the debates in Philadelphia on the same issue, this amount was either too low or too high. Therefore, every state was to establish its own qualifications. As one deputy put it: "it is most convenient that every legislature enacts its own regulation in accordance to its own climate and circumstances, since in some states those with a property worth 25000 pesos will have the right to vote, while in other states those that have more or less [property] will have the vote" (AGUILAR RIVERA, 2000, p. 162). Secondly, some deputies objected to the property qualification because of the unequal wealth distribution obtained during Spanish colonial rule. Property was in the hands of a few individuals. Thus, as we have seen it is quite remarkable that once state legislatures drafted their constitutions they omitted property conditions. For Mexican constitution-makers, unlike their northern neighbors "political community should not be structured around property or income, not even around assessable contributions in the form of taxes $[\ldots]$ neither on enlightenment or civic virtues" (PANI, 2003, p. 91). As Pani asserts, a good citizen was a morally "good" man, a head of family, "firm and solvent", known as such by his neighbors (idem, p. 90).

On June 17, 1823 an electoral law ${ }^{11}$ to elect a new constituent Congress was published (GARCÍA, 1978, p. 33-42). The Cadiz arrangement of indirect elections in three degrees as well as the religious prolegomenon was retained (idem, p. 34) ${ }^{12}$. The wide franchise was also kept: all able men of 18 years of age were enfranchised. However, alleged criminals, debtors, those with an "unknown way of living or residence" and domestic servants were excluded (idem, Art. 17). Note that this piece of legislation, unlike the 1812 Cádiz constitution, did not follow the "principle of distinction". No income or property qualification was required from deputies. With the exception of age and residence voters,

11 It was callded "Bases para las Elecciones del Nuevo Congreso", of 17 June, 1823.

12 Art. 13 "Serán precedidas de rogación pública en las catedrales y parroquias, implorando el auxilio divino para el acierto" (GARCÍA, 1978, p. 34). 
electors (primary and secondary) and deputies were very much alike ${ }^{13}$. Thus, while there were some changes in the electoral law (representation by classes was eliminated) voter eligibility continued under the terms set forth by Iturbide ${ }^{14}$.

No restriction to the vote was to be imposed until 1836. However, as we shall see, in 1830 some new electoral procedures were put in place at the federal level in order to achieve greater control of elections. Electoral units were downsized from large parishes to small manzanas that carried their own primary elections ${ }^{15}$. Also officials were appointed to conduct electoral census. These measures attempted to curb practices which were common, such as the distribution of lists. On November 30, 1836, six

13 Art. 69: "To become deputy it is required to be a citizen in good standing, over 20 years of age, born in the province or having been in residence for at least seven years". Lay persons as well as secular members of the church, members of the provincial Junta as well as non members could become deputies. Oddly enough, there were more restrictions for secondary electors than for deputies. Secondary electors had to be at least 25 years of age with a five year residence in the "partido". Civil, military and e cclesiastic magistrates were excluded as well as priests. Primary electors had to be at least 25 years of age (or 21 if married), neighbor and resident of the municipality. Civil, military and ecclesiastic magistrates were excluded as well as priests. However, elected authorities, such as mayors, were eligible (GÓMEZ, 2005, p. 36-37, 39). The 1823 law imposed more conditions for primary electors than those imposed on parish electors by the 1812 Cádiz Constitution (on which it was modeled after) which (Art. 75), only required full citizenship, 25 years of age and the condition of neighbor and resident (Art. 45). According to the Spanish Constitution, secondary electors, in addition to the requirements for primary electors, could be laymen or secular ecclesiastics. Members as well as non-members of the partido Junta could be elected.

14 When the idea of electing a constituent congress was discussed in 1821, Iturbide proposed that the assembly be filled with representatives of different "classes" according to their importance and influence. The assembly would be composed of 114 citizens plus nine clergy, nine military, nine magistrates, nine lawyers, two farmers, two employees, two artisans, two miners, one "title" and one mayorazgo. This design sought to include significant interest groups. Oddly, this proposal was neither traditional nor modern. It was not Spanish corporatist but clearly was out of touch with modern representative government.

15 A "manzana" was roughly a city "block". years later and a few rebellions, a new electoral law was passed. Political elites seemed to have reached a consensus: they would abstain from tapping into the popular classes in their struggles. Only neighbors with an annual income (rents, salaries) of at least one hundred pesos would now be allowed to vote (idem, p. 58). Previous exclusions were maintained (domestic servants, criminals, debtors, clerics etc.) Indirect elections in three degrees were also preserved ${ }^{16}$. Some states had started to impose property or income restriction even before 1836. Between 1830 and 1832 states such as Veracruz and Guanajuato imposed different restrictions (SERRANO \& CHUST, 2008, p. 221-222).

Having reached a provisional agreement regarding the exclusion of the "dangerous classes" it is sensible to assume that such consensus among the political elites would last for many years, until democratic pressures resulted in the gradual opening of the franchise. However, that was not the case in Mexico. Only five years after the electoral law of November 1836 was enacted a coalition of disgruntled merchants and generals (among them Santa Anna and Paredes Arrillaga) was formed to oust (for the second time) President Anastasio Bustamante ${ }^{17}$. Santa Anna suspended de 1836 centralist constitution and proposed to convene a constituent Congress based on a new electoral law. A committee was appointed to draft the new legislation. The authors suggested that the June 1823 electoral law "be reinstated because of its 'greater acceptance' among the people. The more restrictive laws of 1830 and 1836 were reviewed, the motivations of their perpetrators questioned, and their results condemned. The committee denounced as 'pretexts of deception' the efforts to blame instability on the "natural character' of a new nation, and the laws of 1830 and 1836 were described as a desperate effort to

16 Indirect elections remained in place in Mexico until 1911. The three-stage Cádiz model was in place until 1857 and from then on there was a two-stage system (VARELA ORTEGA \& MEDINA PEÑA, 2000, p. 208).

17 Bustamante was in power for the first time between 1830 and 1832 (January 1, 1830 to August 30, 1832), later in 1837 he was elected to the presidency. He served as President, from April 191837 until September 221841 with a brief four months interruption (March 18, 1839 to July 18, 1839), when he was toppled by Santa Anna and Paredes Arrillaga. 
control, electoral outcomes and deny the popular will” (OROZCO, 1978, p. 71-80). The electoral decree of December 10, 1841 removed income qualifications for voters but preserved a property restriction for deputies (ibidem $)^{18}$. Small electoral units, a required census and the distribution of ballots by electoral commissioners, all provided by the 1830 law, were preserved. Also, there were some differences in the conditions imposed on primary and secondary electors (WARREN, 1996, p. 51).

The strategy of restricting the franchise was not a stable equilibrium among political elites. In the next five years income qualifications to voters were repealed and adopted again several times. Why was the consensus to exclude the lower classes from the elections so weak? Perhaps, the temptation of employing popular mobilization was very strong. After a few years Santa Anna realized that he was depriving himself of a valuable weapon: the popular vote ${ }^{19}$. Not all the elites agreed on this point. There is evidence that many in the provinces wanted property or income and literacy qualifications for voters and candidates and supported the idea of the representatives being restricted to heads of family (COSTELOE, 1989, p. 260). Other ideas took shape: the departments now asked for equality of representation regardless of population. They demanded four deputies from each of the 24 departments regardless of size of population. The committee adopted many of the suggestions, particularly that population should no longer determine the number of deputies and that each department should be allocated four deputies. However Santa Anna did not accept the committee's report. He instead imposed by decree the electoral regulations of December 1841 that excluded these innovations.

\footnotetext{
18 An exclusion was added: regular clergymen could not vote. Primary electors, unlike regular citizens, had to be at least 21 years old, they had to be neighbors and residents of the municipality and magistrates were excluded. Besides these qualifications, secondary electors had to be at least 25 years of age and residents for at least one year in the municipality. Finally, deputies had to have two years of residence and an annual income of at least 1500 pesos. Married men, widowers and heads of families were to be preferred to single men (OROZCO, 1978, p. 74-77).

19 However, if this is the case why was the income
} restriction to candidates preserved?
Santa Anna "had clearly rejected the demands from the provinces to restrict the franchise. There was to be no literacy test, property or income qualification for voters, and had resisted the considerable pressure to grant equality of representation in the Congress for all departments irrespective of their size or population" (idem, $\mathrm{p}$. 262). Indeed, Santa Anna's behavior is difficult to explain. As Costeloe suggest, miscalculation might be the answer. Santa Anna presumably resisted the pressure of the regions for a more restricted franchise because he believed that he could and would win the elections through mobilizing the popular vote despite the fact that he made no effort to build a political constituency of his own (idem, p. 269). He was wrong.

The Congress met in June 1842 produced a draft constitution that Santa Anna disliked and, after a pronunciamiento took place, he closed the Congress in December. The way was opened for an advisory council chosen by him to endow him with dictatorial powers. The Junta Nacional Legislativa drafted a centralist constitution, the 1843 Bases Orgánicas. Under the electoral provisions of the Bases, Santa Anna was elected President and was inaugurated in 1844. As it had been since 1830 , electoral sections were small (500 inhabitants). A bicameral legislative was established. Elections were indirect in three stages. Citizenship was restricted to males, 21 years of age (or 18 if they were married) with an annual income of at least 200 pesos. Future congresses could adjust this amount to the conditions of each of the departments to enjoy full rights of citizenship. Registering in the electoral census, voting and serving were duties imposed on citizens (GARCÍA, 1978, p. 80-83). In addition, a condition of literacy would be added starting in 1850 . Secondary electors were required an income of 500 pesos but Congress could change this amount in the future. Deputies had to be at least 30 years of age and have an annual income of at least 1200 pesos. Senators should be at least 35 years of age and have a substantial annual income of at least 2000 pesos. The Senate was conceived as representing interests, similar to earlier Iturbide's proposal. Two-thirds (42) of the 63 -members chamber were to be elected by the departmental assemblies. However, they were required by the charter to elect five individuals of each of the following classes: farmers, miners, property-holders or merchants and manufactu- 
rers. These individuals were exempt from the 2 000 pesos income qualification. The remaining senators were to be former presidents, vice presidents, two-time deputies, ministers, ambassadors, state governors, bishops or division generals.

Santa Anna ruled the country until December 1844, when his government was toppled by a coup orchestrated by disaffected politicians. Congress appointed Joaquín de Herrera in his place. He, in turn, was ousted in December 1845 by Gen. Mariano Paredes y Arrillaga. The war with the United States began in 1846 and in April Gen. Álvarez rebelled against the government in the south of the country. Likewise, on August 6, 1846 Gen. Mariano Salas issued a pronunciamiento in Mexico City. The Plan de la Ciudadela called for the convocation of a new constituent Congress. Paredes was toppled on August 6, 1846 in the midst of the war against the Americans. On August 6, 1846 the convocatoria was issued. The electoral law to be used to elect the Congress was the June 17, 1823, with certain amendments (idem, p. 111-119). The broad franchise of the early Federal Republic was reinstated. On August 22, 1846 the 1824 constitution was restored. Elections to elect an extraordinary Congress were held at the end of 1846. The electoral law used was the inclusive December 10, 1841 law. The new constituent Congress restored the 1824 constitution. An Act of Reforms (amendments) was attached to the charter. The Act of Amedments, authored by liberal Mariano Otero, was approved on May, 18, 1847. It asserted that: "every Mexican national, either by birth or by naturalization, of 20 years of age, that has an honest mode of subsistence, and that has not been convicted of a criminal offense, is a citizen of the Mexican United States". Likewise, article 2 stated that citizens had the "right to vote in popular elections" (MEXICO, $1847)^{20}$. On June 3, 1847, a new electoral law was passed by the constituent Congress that

20 "Art. $1^{\circ}$ Todo mexicano, por nacimiento ó por naturalización, que haya llegado á la edad de veinte años, que tenga modo honesto de vivir, y que no haya sido condenado en proceso legal á alguna pena infamante, es ciudadano de los Estados-Unidos Mexicanos. Art. $2^{\circ}$ Es derecho de los ciudadanos votar en las elecciones populares, ejercer el de petición, reunirse para discutir los negocios públicos, y pertenecer á la Guardia Nacional, todo conforme á las leyes. Art. $3^{\circ}$ El ejercicio de los followed the provisions of both, the Acta de Reformas and the December 10, 1841 law (GARCÍA, 1978, p. 120-122). It established nearly universal male suffrage. Thus Mexico, Greece and El Salvador, became the only countries "with broad male suffrage as of 1847 " (PRZEWORSKI, 2010, p. 50).

All in all, between 1821 and 1857 income restrictions to voters had been in effect less than nine years ${ }^{21}$. Income or property qualifications were never imposed again in the 19th century. Yet the condition of "having a known means of subsistence" or an "honest means of subsistence" was not challenged. The 1857 constitution enshrined universal male suffrage and provided that the only conditions to citizenship were age (20 years if single, 18 if married) and having an honest mode of living (Art. 34) (GARCÍA, 1978, p. 55, 155). In the 1856-1857 Constituent Congress there was debate over the proposal of imposing a literacy condition to the right to vote. Also, indirect elections were challenged by some constitution-makers. To the question: who is to control electoral procedures they offered different answers For some, such as Francisco Zarco and Ignacio Ramírez indirect elections deceived the people. Others, alleged that the time to establish direct elections had not come, since priests still were very influential with the people (VARELA \& MEDINA, 2000, p. 206). The second group prevailed and indirect elections were adopted for representatives, justices and the executive, but with one change: there were to be two instead of three stages (arts. 55, 76 and 92). Indirect elections in two stages were in place in Mexico until 1911. Thus, for very long time male universal suffrage coexisted with indirect elections. However, interestingly enough, after 1857 many state constitutions often provided for direct

derechos de ciudadano se suspende por ser ebrio consuetudinario, ó tahur de profesion, ó vago; por el estado religioso, por el de interdicción legal; en virtud de proceso sobre aquellos delitos por los cuales se pierde la cualidad de ciudadano, y por rehusarse, sin excusa legítima, á servir los cargos públicos de nombramiento popular" (MEXICO, 1847, arts. 1-3).

21 Property restrictions were in place in Mexico during the central republic during the following periods: between November 30, 1836 and December 10, 1841 and between June 14, 1843 and August 6, 1846. 
election: in 13 states the local Congress and the governor were elected by "direct and popular vote" (CARMAGNANI, 1991, p. 235)22.

\section{THE IMPOSSIBILITY OF THE ELITIST \\ CONSENSUS: ELECTORAL PRACTICES AND POPULAR MOBILIZATION}

In spite of the fact that the voting franchise was expanded in 1821 and 1823, (with the elimination of the racial restrictions of the Cádiz charter) at the beginning of the republican period, participation declined in the first elections as an independent nation. However, the lack of a racial restriction made possible the careers of politicians such as Benito Juárez, a Zapotec Indian. For instance, in the parish of Sagrario of Mexico City 5,392 citizens voted in the 1812 municipal council primary elections while only 412 persons voted in 1823 . Yet, this quickly changed after 1824. In the 1826 Mexico City's congressional primary election 30000 ballots were cast in. According to Warren, political ferment, like that of 1812 , was "directly related to the organizing initiatives of an aspiring elite faction: radical federalists organized in York rite Masonic lodges" (WARREN, 1996, p. 42). It seems that right from the Cadiz experiments mobilization did not depend on the opportunity to vote, in terms of enfranchisement, but was instead triggered by party politics. In 1826 Yorkino machinations were extremely successful as an unprecedented number of ballots were counted, and their candidates dominated as primary electors. Opponents claimed the yorkinos purchased votes and used urban mobs for political ends. The Scottish rite followers accused the yorkinos of purchasing and destroying escocés candidates lists in poor neighborhoods. The game of mobilizing popular support was played by the two major political factions. This helps to explain the "size and intensity" of popular participation.

Factional conflict did no cease after the 1826 congressional elections. It deepened and reached

22 Even before 1857, in the first state constitutions of the 1820 , there were some departures from the Cadiz model. For instance, there were different mechanisms to elect governors. In some states the local executive was elected by municipal councils (ayuntamientos), while in others it was elected by the local congress and yet in others it was elected by electoral colleges. a climax two years later, in the 1828 presidential elections ${ }^{23}$. This election might be considered a "critical juncture". Until that election both factions shared cabinet posts as well as other power positions in the national government of gen. Guadalupe Victoria. The yorkino candidate, Gen. Vicente Guerrero, lost the election and a few months later constitutional regularity broke down (DI TELLA, 1994, p. 200-225). The escocés Manuel Gómez Pedraza was elected President, but before his inauguration took place a revolt broke out in Mexico City. Gómez Pedraza was prevented from assuming office and Congress elected the defeated candidate, Guerrero, as President.

Why did Guerrero subvert the constitutional order? This is a key episode in the development of elections and representative government in Mexico. A new presidential election was scheduled in 1832 , four years later. In the hotly contested elections of 1826 and 1828 turnout may have been as high as $75 \%$ of the adult male population (WARREN, 2001, p. 164). A possible answer is that, along with yorkino recklessness, popular mobilization went out of control. Indeed, on December 4 1828, when Gómez Pedraza was about to capitulate, and in a frenzy of popular and military resentment against the Spaniards, "a mob descended on the Parián market and pillaged its shops as well as a number of homes and businesses elsewhere in the city center. Estimates of the number of participants in the riot range up to several thousand. The upheaval drove most people of means off the streets for several days, including the municipal council officers who were supposed to preserve public tranquility". Thus, the Parián riot in Mexico City became the great symbol of 1820 s popular radicalism. Conservatives claimed that the Parián booty was offered as a reward to the poor for supporting Guerrero. The looting itself confirmed conservative fears of the relationship between popular political participation and social dissolution, while radicals explained the event as an "understandable response to three hundred years of Spanish oppression and the repeated aristocratic conspiracies of the post-independence era promulgated by those who survived off the sweat of the Mexican people" (ibidem). Mexico City's

23 While the executive was chosen by the state legislatures, "the uses of popular pressure had become an essential element of contemporary politics" (WARREN, 1996, p. 44). 
largest uprising in over one hundred years came about directly as a result of partisan politics. Also it came about as the failure of elections to channel political participation. While the 1828 election was not the first election in which party politics and mass mobilization intersected (as we have seen the 1812 election exhibited both traits), it was the first in which losers had enough incentives (and means) to subvert the process ${ }^{24}$. They were indeed successful in their attempt of altering the formal outcome of the elections. The background of constitutional breakdown was the poor state of the economy, xenophobic agitation against the Spaniards and miners unrest. However, many among the political elites saw the Parián riot basically as the inevitable result of the political enfranchisement of the urban poor. Something close to a consensus emerged. Thus the movement towards restricting the vote began.

After Guerrero was deposed in 1829 by a pronunciamiento in the city of Jalapa the Vice President, General Anastasio Bustamante, took charge of the presidency and Lucas Alamán became Minister of the Interior. In his first ministerial report to Congress, submitted in February 1830, Alamán singled out the causes of the ills of the country. The system of elections came only second after secret societies. Alamán criticized that during elections the factions distributed lists of candidates, secured for themselves the positions of secretary and inspector at the polling tables, thereafter every person, regardless of qualifications, was allowed to vote sometimes more than one time. He believed these practices made judicious men turn away from elections, leaving the field in the hands of those less able of conducting them with tact. The "spirit of party" went so far as to consider property and enlightenment as aristocratic and excluding them from elections. Such qualities were the "sole basis of a truly representative system" (ALAMÁN, 1945, p. $183-185)^{25}$.

\footnotetext{
24 Nothing comparable to the Parián riot came about even during the more critical moments of the November 1812 election in Mexico City.

25 Often men were elected who did not depend on society by any bond, and whom "having nothing aspired to gaining everything" without scruples. Because of these facts, Alamán, asserted, elections often lacked legitimacy. Since political authority had been weakened by revolution only "immaculate" electoral processes could endow such authorities with sufficient legitimacy.
}

Alamán was not alone in his criticism of elections. José María Luis Mora, a luminary of the liberal party, was very much in agreement with him. Two months after Alamán gave his report, Mora published an extended article in the daily $E l$ Observador in which he argued for the establishment of property qualifications (MORA, 1994, p. 136-145 $)^{26}$. Mora suggested a minimum income requirement of 1000 pesos annually or real state property worth 6000 pesos. Such amounts would be cut in half in the countryside and in towns with less than 10000 inhabitants. Mora also argued for a uniform national citizenship. National citizenship would be a requirement to acquire state citizenship.

However, Mora's proposal was not adopted by the Bustamante government, which had its own ideas on electoral reform (WARREN, 1996, p. 45). As we have seen, in July 1830 the government persuaded Congress to pass a major electoral reform bill for the Federal District and Territories intended to restrict access to the ballot box. However, no income restriction was adopted. The basic electoral units for the Federal District were changed from the 14 parishes to 245 small manzanas $^{27}$.

26 Mora blamed much of Mexico's instability on a misguided notion of equality. There had been a "scandalous profusion" of political rights that had allowed even the lowest classes of society participation in elections. Spain, Portugal, Naples and "all the new republics of America that adopted the principles of the Spanish constitution of extending the exercise of political rights to non property holders have marched relentlessly from one revolution to the other" (MORA, 1994). In contrast, Mora admired the electoral systems of the United States, Britain and Holland because of the stability of those systems which he attributed to a restricted franchise. Mora published a series of interesting articles regarding elections: Mora (1830a; 1830b).

27 Under the new system, each of the 245 manzanas would have its own primary election, "short-circuiting the mass production of printed candidates lists and the possibility of gathering large groups at the polls". Moreover, each manzana would have one electoral commissioner, an official designated by the municipal council to conduct a neighborhood census and distribute ballots to eligible voters well before election day. This measure was designed to cut down on multiple voting by individuals and ineligible persons. The municipal council now controlled the appointment of electoral commissioners, who in turn conducted the electoral census, handing out or denying ballots "to whomever they chose and, significantly, reporting vagrants (whom would not be able to vote) to the police" (WARREN, 1996, p. 5). 
The following year Alamán optimistically reported to Congress that the new law had "cut from the root the abuses in popular elections" (ALAMÁN, 1945, p. 26) ${ }^{28}$. However, as Warren notes, the change in administrative apparatus did not interrupt the electoral process much at first and the transition to the manzana system "did not result in an immediate decline in voter turnout, either. Aggregate turnout in municipal elections was virtually the same in 1830 (12 218) and 1831 (12 581) as it was in 1829 (13 028), prior to the change in the law" (WARREN, 1996, 45-46). Under the new system, however, commissioners fared very well. In most manzanas the commissioners won the primary elections. In 1831 approximately 45 per cent of the winners were commissioners. Thus this shows that they became key political operatives. The elections of 1830 and 1831 demonstrated that the 1830 electoral reform "was not sufficient to curtail voter turnout or secure conservative victory" (ibidem).

In the 1832 municipal elections of Mexico City prominent liberals claimed that the elections had been conducted in an atmosphere of fear, which brought into office persons who did not merit the "confidence of the people". A new revolt staged by a liberal coalition allied with Santa Anna ousted Bustamante and Alamán from power. The new administration, headed by the Vice President Valentín Gómez Farías, dissolved the sitting municipal council and summoned the 1829 members to return. Once more, formal results of the elections were reversed. This had an adverse effect on electoral participation. The 1833 municipal election was "marked by widespread absenteeism". The new government blamed the 1830 law for the decrease in participation. Vice President Gómez Farías, a liberal, was resolved to prosecute the ministers of the deposed Bustamante administration, in particular Alamán, who went into hiding to avoid arrest. There the ex minister wrote an account of the flaws of the 1824 constitution (ALAMÁN, 2008) ${ }^{29}$.

28 While the law had some flaws these would in time be corrected. The problem now, he pointed out, was that voters did not vote. To correct this he proposed to fine absentee voters. Alamán proposed to fine absentee voters with 2 to 10 pesos.

29 In his account Alamán sided with Mora. Income or property restrictions to voters were never as necessary as when a new nation adopted the representative
From 1833 to 1835 political apathy continued. Electoral reform was a priority in 1835 when the centralists won power and decided to draft a new constitution. They introduced the first income restrictions on the suffrage shortly thereafter. Why? Absenteeism was undeniable. In the 1835 Mexico City elections only 32 manzanas out of 60 held elections. According to the electoral census, turnout was $23.6 \%$. In the manzanas that had elections turnout was $27.7 \%$. However the key was in who voted. According to Warren, the breakdown of voters by profession shows a surprising, but undeniable pattern: "there was a high participation rate by poorer artisans and manual laborers. Shoemakers and carpenters as well as load bearers, water carriers and bricklayers voted in significant numbers. In manzanas with elections, more than $47 \%$ of water carriers and more than $37 \%$ of carpenters and bricklayers cast votes, versus the overall voter turnout of 27.7\%" (WARREN, 1996, p. 47) 30 . In 1835 the main electoral constituency were the poor.

Elections were seen by many prominent actors as key to explaining the ills of the country. By early 1846 Mexico had been celebrating elections for more than 30 years. In 1836, after 15 years of experimenting with an expansive franchise, Mexican elites decided, for the first time, to impose income or property qualifications for voters. At the beginning of the early republican period representation was so democratic that not even the principle of distinction, key to representative government, was followed. This is quite different from what happened in older representative governments. In Mexico City turnout for municipal elections in the period from 1829 to 1831 hovered around $27 \%$ of the city's estimated total male population (idem, p. 161). It had taken years to political elites to agree on the need to restrict the franchise. Much had been expected from elections. Now, a peculiar disbelief captured the minds of some long-standing observers and participants. The prospect of

government for the first time. He also criticized indirect elections. As a filter of the popular will they were useless, he argued, since the qualifications for primary and secondary electors were the same.

30 "Ley sobre elecciones de diputados para el Congreso general, y de los individuos que compongan las juntas departamentales" (GARCÍA, 1978, p. 58). 
reforming the electoral system looked grim. Adopting long overdue income restrictions to the franchise had clearly not been enough to "fix" the system. Besides, as events had shown, such restrictions did not constitute a stable equilibrium, since many political actors from all factions had incentives to deviate from it. Mass politics was a valuable resource and it was hard to abstain from it. Thus, Alamán and other conservatives reached the conclusion that not even indirect, incomerestricted, elections would do. They believed that something else had to be tried, a new system different from those of England, the U.S. and France. In designing this original system he tapped into ideas of class and interest representation already contained in the 1821 Iturbide's convocation and in the 1843 Bases Orgánicas. Only this time he took his proposal even farther away from standard theories of representation (VÁZQUEZ, 1999, p. 122). To preserve order and stability a corporatist representation system would be established ${ }^{31}$. This project was afforded little time since as we have seen, the Paredes government was ousted only seven months after the publication of the convocatoria. The federal republic - and its electoral regime - were restored. Alamán saw these developments as a return to the stormy 1820's, an era of mass elections that he decried. Riots had gripped Mexico City in 1838, 1841 and 1844 (WARREN, 1996, p. 169). Further radicalization ensued in the following years. Thus, four years later, in 1853, he complained to Santa Anna that the conservative party, which he now led, was set against the representative system, "against elective townships, and against everything called popular election until the time where they lay on a different foundation" (ALAMÁN, 1986, p. 313-17).

\section{CONCLUSIONS: MACHINE POLITICS IN MEXICO}

After the Reform War (1857-1861) and the fall of the Second Empire (1863-1867) liberals

31 The proposed electoral system was detailed and extremely complex. Congress would be composed of 160 deputies to be distributed among nine different classes: country and urban property and agricultural industry, (38 deputies) trade (20 deputies), mining (14 deputies), manufacturing (14 deputies), literary professions (14 deputies), magistracy (10 deputies), public administration (10 deputies), clergy (20 deputies) and the Army (20 deputies) enjoyed political supremacy. As we have seen, from the beginning of the republican period an expanded franchise was the product of political competition between the elites that actively used the popular classes in the factional struggles. However, elites also wanted to preserve control over electoral process, thus the long-lived system of indirect elections. This case seems to run counter to some social science explanations of how the franchise expanded (ACEMOLGLU \& ROBINSON, 2006). During the era of the Restored Republic (1867-1876) elections became contests between the federal and local governments. The electoral system empowered local authorities, since prior to the biennial federal elections, the municipal councils designated the electoral census takers, polling sites, and a citizen charged with setting up the polling table (VARELA ORTEGA \& MEDINA PEÑA, 2000, p. 210-211) ${ }^{32}$. Thus the national government competed with local politicians for the control of voters and electors. Presidents during the Restored Republic need governors if they wanted to be reelected. Some governors cooperated, other did not. When presidents, such as Benito Juárez, faced a hostile governor they frequently resorted to military intervention to depose it and place a factional ally. Governors were key to decide elections because they in turn controlled the "jefes politicos", officials created by the Cádiz constitution that had authority over local mayors. Juarez and his ally, Sebastián Lerdo de Tejada, controlled the majority of governors. In this way they were able to prevent Díaz, who had few governors, from winning an election. The result was the failed 1871 Díaz rebellion. A key complaint was that Juárez used his factional allies to make a travesty of elections. Díaz could not defeat the electoral machine. Thus, as Medina asserts, the Díaz 1871 and 1876 rebellions, as well as the 1910 Francisco I. Madero revolution, were directed against the "use and abuse" of

32 The polling station was completed with the first seven citizens that showed up. These citizens designated a President, a secretary and the inspectors. The officials took the ballots where the citizens had written the names of their preferred elector. Following the Cadiz model, the polling table could decide, without appeal, any complaint on the election. After these vote section electors traveled to the capital of the district. There they voted with secret ballots to elect the deputies. Candidates had to carry an absolute majority of electoral votes. Similar procedures 
electoral rules. In 1876 Juárez was dead and Lerdo could not keep the machine together. Fraud prevailed and Díaz rebelled again, this time he was successful in toppling the government. He would construct his own electoral machine that lasted for 34 years, until it, too, crashed. were followed in the election of President and justices of the Supreme Court. Once the deputies were elected the documentation was sent to the Chamber of Deputies that passed judgment, as electoral college, on the election. With minor changes these procedures were in place until 1911 In 1874 the Senate was restored.

José Antonio Aguilar Rivera (joseantonio.aguilar@cide.edu) é Doutor em Ciência Política pelo Centro de Investigación y Docencia Económicas (México).

\section{REFERÊNCIAS BIBLIOGRÁFICAS}

ACEMOGLU, D. \& ROBINSON, J. A. 2006. Economic Origins of Dictatorship and Democracy. New York: Cambridge University.

ADAMS, J. 1856. The Works of John Adams, Second President of the United States. Boston: Little Brown.

AGUILAR RIVERA, J. A. 2000. En pos de la quimera. Mexico: Fondo de Cultura Económica.

ALAMÁN, L. 1945. Memoria de la Secretaría de Estado y del Despacho de Relaciones Interiores y Esteriores, leída por el Secretario del ramo en la Cámara de Diputados el día 12 de febrero de 1830, y en la de senadores el día 13 del mismo. In:_. Obras de D. Lucas Alamán. Documentos diversos (inéditos y muy raros). V. 1. Mexico: Jus.

1986. Carta a Santa Anna [1852]. In: GARCÍA CANTÚ, G. (ed.). El pensamiento de la reacción mexicana (1810-1859). V. 1. Mexico: UNAM.

2008. Examen imparcial de la administración de Bustamante. Mexico: Conaculta.

ANNINO, A. 1995. Cádizy la revolución territorial de los pueblos mexicanos, 1812-1821. In: (ed.). Historia de las elecciones en Iberoamérica, siglo XIX. Buenos Aires: Fondo de Cultura Económica.

1996. The Ballot, Land and Sovereignty: Cádiz and the Origins of Mexican Local Government, 1812-1820. In: POSADACARBÓ, E. (ed.). Elections Before Democracy: The History of Elections in Europe and Latin America. London: MacMillan.

ÁVILA, A. 1999. En nombre de la nación. La formación del gobierno representativo en México. Mexico: Taurus.

2004. El partido popular en México. Historia y Política, Madrid, v. 11, n. 1, p. 35-65.

BELLINGERI, M. 1995. Las ambigüedades del voto en Yucatán. Representación y gobierno en una formación interétnica, 1812-1829. In: ANNINO, A. (ed.). Historia de las elecciones en Iberoamérica, siglo XIX. Buenos Aires: Fondo de Cultura Económica.

BENSON, N. 1946. The Contested Mexican Election of 1812. The Hispanic American Historical Review, Durham, v. 26, n. 3, p. 336-350.

1955. La Diputación Provincial y el federalismo mexicano. Mexico: El Colegio de México.

2004. The Elections of 1809: Transforming Political Culture in New Spain. Mexican Studies, Berkeley, v. 20, n. 1, p. 1-20, Winter.

BREÑA, R. 2006. El primer liberalismo español y los procesos de emancipación de América, 1808-1824. Una revisión historiográfica del liberalismo hispánico. México: El Colegio de México.

CARMAGNANI, M. 1986. La libertad, el poder y el estado en la segunda mitad del siglo XIX. Historias, Buenos Aires, n. 15, p. 55-84, oct.dic. Disponível em: http://www.estudios historicos.inah.gob.mx/revistaHistorias/wpcontent/uploads/historias_15_55-64.pdf. Acesso em: 26.abr.2012.

1989. El liberalismo, los impuestos internos y el Estado federal mexicano (18571911). Historia Mexicana, Ciudad del Mexico, 
v. 38, n. 3, p. 471-496. Disponível em: http:/ /codex.colmex.mx:8991/exlibris/aleph/a18_1/ apache_media/HHHJ1YNBQJAAVSJG4KM̄ 6 BLAIAM6NB2.pdf. Acesso em: 26.abr.2012.

1991. Del territorio a la región. Líneas de un proceso en la primera mitad del siglo XIX. In: HERNÁNDEZ, A. \& MIÑO, M. (eds.). Cincuenta años de historia en México. V. 2. México: El Colegio de México.

. 1993. El federalismo liberal mexicano. In: CARMAGNANI, M. (ed.). Federalismos latinoamericanos: México/Brasil/Argentina. Ciudad del Mexico: Fondo de Cultura Económica.

CASTILLO, N. 2003. Cambios y continuidades entre las repúblicas indias y los ayuntamientos constitucionales de Cholula, 1768-1865. In: CONNAUGhTON, B. (ed.). Poder $y$ legitimidad en México en el siglo XIX. Instituciones y cultura política. Mexico: Porrúa.

CHUST M. 1999. La cuestión nacional americana en las Cortes de Cádiz. Valencia: UNAM.

CONNAUghton, B. (ed.). 2003. Poder y legitimidad en México en el siglo XIX. Instituciones y cultura política. Ciudad del Mexico: Porrúa.

COSTELOE, M. 1989. Generals versus Politicians: Santa Anna and the 1842 Congressional Elections in Mexico. Bulletin of Latin American Research, Oxford, v. 8, n. 2, p. 257-274.

1996. La primera república federal de México (1824-1836). Ciudad del México: Fondo de Cultura Económica.

2000. La República central en México, 1835-1846: "hombres de bien" en la época de Santa Anna. Ciudad del Mexico: Fondo de Cultura Económica.

DI TELLA, T. 1994. Política nacional y popular en México 1820-1847. Ciudad del México: Fondo de Cultura Económica.

EMMERICH, G. 1985. Las elecciones en México, 1808-1911: ¿sufragio efectivo? ¿no reelección? In: CASANOVA, P. G. (ed.). Las elecciones en México: evolución y perspectivas. Ciudad de Mexico: Siglo XXI.
ESCOBAR, A. 1996. Del gobierno indígena al ayuntamiento constitucional en las Huastecas hidalguense y veracruzana, 1780-1853. Mexican Studies, Berkeley, v. 12, n. 1 p. 127, Winter.

FALCON, R. 1988. La desaparición de jefes políticos en Coahuila. Una paradoja porfirista. Historia Mexicana, v. 27, n. 3, p. 423-457. Disponível em: http://codex.colmex.mx:8991/ exlibris/aleph/a18_1/apache_media/ 88RT5MQA6HRYG6PFXJUQ8B5NUH4GVS. pdf. Acesso em: 26.abr.2012.

FOWLER, W. \& MORALES, H. (eds.). 1999. El conservadurismo mexicano en el siglo XIX. Puebla: Benemérita Universidad Autónoma de Puebla.

GÓMEZ, J. O. 2005. Legislación en telecomunicaciones. Ciudad del Mexico: Porrúa

GUARDINO, P. 1998. Total Liberty in Casting our Ballots: Plebes, Peasants, and Elections in Oaxaca, 1808-1850. Trabalho apresentado no Annual Meeting of the Latin American Studies Association, realizado em Chicago, de 24 a 26 de setembro. Digit. Disponível em: http://bibliotecavirtual.clacso.org.ar/ar/libros/ lasa98/Guardino.pdf. Acesso em: 26.abr.2012.

2003. "El carácter tumultuoso de esta gente": los tumultos y la legitimidad en los pueblos oaxaqueños, 1768-1853. In: CONNAUGHTON, (ed.). Podery legitimidad en México en el siglo XIX. Instituciones y cultura política. Ciudad del Mexico: Porrúa.

2007. El nombre conocido de república. Municipios en Oaxaca, de Cádiz a la primera república federal. In: ORTÍZ ESCAMILLA, J. \& SERRANO, J. A. (eds.). Ayuntamientos y liberalismo gaditano en México. Zamora: Colegio de Michoacán.

GUEDEA, V. 1991a. Las primeras elecciones populares en la ciudad de México, 1812-1813. Mexican Studies, Berkeley, v. 7, n. 1, p. 1-29, Winter.

1991b. Los procesos electorales insurgentes. Estudios de Historia Novohispana, $\mathrm{n}$. 11, p. 201-249. Disponível em: http:// www.revistas.unam.mx/index.php/ehn/article/ download/3339/2894. Acesso em: 26.abr.2012.

2001. El pueblo de México y la política 
capitalina, 1812-1813. Mexican Studies, Berkeley, v. 10, n. 1, p. 27-63, Winter.

GUERRA, F. X. 1980. The Spanish-American Tradition of Representation and its European Roots. Journal of Latin American Studies, Cambridge (UK), v. 26, n. 1, p. 1-35, Feb.

1992. Modernidad e independencias. Ciudad del Mexico: Fondo de Cultura Económica.

1999. El soberano y su reino. Reflexiones sobre la génesis del ciudadano en América Latina. In: SABATO, H. (ed.). Ciudadanía política y formación de las naciones. Perspectivas históricas de América Latina. Ciudad del Mexico: Fondo de Cultura Económica.

MORA, J. M. L. 1830a. Discurso sobre elecciones. El Observador, 14.mayo.

1830b. Sobre las elecciones próximas. $E l$ Observador, 9.junio.

1994. Mora legislador. Ciudad del Mexico: Cámara de Diputados.

OROZCO, A. G. 1978. Legislación electoral mexicana 1812-1977. Ciudad del Mexico: Comisión Federal Electoral.

ORTÍZ, J. \& SERRANO, J. A. (eds.). 2007. Ayuntamientos y liberalismo gaditano en México. Zamora: Universidad Veracruzana.

PALTI, J. E. 2003. La Sociedad Filarmónica del Pito. Ópera, prensa y política en la República Restaurada (México, 1867-1876). Historia Mexicana, Ciudad del Mexico, v. 52, n. 4, p. 941-977. Disponível em: http://codex. colmex.mx:8991/exlibris/aleph/a18_1/ apache_media/LCVT2FDYDDA 7 YTYJKEVLQPLKGN1X7U.pdf. Acesso em: 26.abr.2012

PANI, E. 2003. Ciudadanos, cuerpos, intereses. Las incertidumbres de la representación. Estados Unidos 1776-1787-México, 18081828. Historia Mexicana, Ciudad del Mexico, v. 53, n. 1, p. 97-100. Disponível em: http:// codex.colmex.mx:8991/exlibris/aleph/a18_1/ apache_media/KH6FAX1N8ENU29 BAM2 EFD7CNLCULLD.pdf. Acesso em: 26.abr.2012.
PERRY, L. B. 1978. Juárez and Díaz. Machine Politics in Mexico. De Kalb: Nothern Illinois University.

PRZEWORSKI, A. 2010. Democracy and the Limits of Self-Government. New York: Cambridge University.

RODRÍGUEZ, O. J. 2005a. The Origins of Constitutionalism and Liberalism in Mexico. In: . (ed.). The Divine Charter. Constitutionalism in Nineteenth-century Mexico. Lanham: Rowman and Littlefield.

. 2005b. 'Ningún Pueblo es superior a otro': Oaxaca and Mexican Federalism. In:

(ed.). The Divine Charter. Constitutionalism in Nineteenth-century Mexico. Lanham: Rowman and Littlefield.

2008. "Equality! The Sacred right of Equality". Representation under Constitution of 1812. Revista de Indias, Madrid, v. 68, n. 242, p. 97-122. Disponível em: http:// revistadeindias.revistas.csic.es/index.php/ revistadeindias/article/view/636/702. Acesso em: 26.abr.2012.

SERRANO, J. A. 2007. Ciudadanos naturales. Pueblos de indios y ayuntamientos en Guanajuato, 1820-1827. In: ORTÍZ ESCAMILLA, J. \& SERRANO, J. A. (eds.). 2007. Ayuntamientos y liberalismo gaditano en México. Zamora: El Colegio de Michoacán.

SERRANO, J. A. \& CHUST, M. 2008. Adiós a Cádiz: el liberalismo, el doceañismo y la revolución en México, 1820-1835. In: RODRÍGUEZ, O. J. (ed.). Las nuevas naciones. España y México 1800-1850. Madrid: Fundación Mapfre.

SORDO, R. 1994. El Congreso y la formación del Estado-nación en México, 1821-1855. In: VÁZQUEZ, J. (ed.). La fundación del Estado mexicano, 1821-1855. Ciudad del Mexico: Nueva Imagen.

VARELA ORTEGA, J. \& MEDINA PEÑA, L. 2000. Elecciones, alternancia y democracia. España-México, una reflexión comparativa. Madrid: Biblioteca Nueva.

VÁZQUEZ, J. 1999. Centralistas, conservadores y monarquistas 1830-1853. In: FOWLER, W. \& MORALES, H. (eds.). El conservadurismo 
mexicano en el siglo XIX. Puebla: Benemérita Universidad Autónoma de Puebla.

VILLEGAS, D. C. 1953. Historia moderna de México. V. 1. Ciudad del Mexico: Hermes.

1957. La constitución de 1857 y sus críticos. Ciudad del Mexico: Hermes.
WARREN, R. 1996. Elections and Popular Political Participation in Mexico, 1808-1836. In: PELOSO V. \& TENENBAUM, B. (eds.). Liberals, Politics and Power. Athens (GA): The University of Georgia.

2001. Vagrants and Citizens. Politics and the Masses in Mexico City from Colony to Republic. Wilmington (DE): SR.

\section{OUTRAFONTE}

MEXICO. 1847. Acta Constitutiva y Reformas sancionada por el Congreso extraordinario constituyente de los Estados-Unidos Mexicanos el 18 de Mayo de 1847. Ciudad de Mexico: Imprenta de Cumplido. 


\section{BEYOND THE RESTRICTIVE CONSENSUS: ELECTIONS IN MEXICO (1809-1847)}

José Antonio Aguilar Rivera

This essay looks at experiments with a system of representation taking place in New Spain and later in Mexico. The elections that were carried out during the days of Spanish rule dealt expediently with the political dynamics of this form of government, such as broad-based political participation. . We study the elections during the early decades of independence through the beginning of the war with the United States, and we find that in spite of the fact that during the 1830s there was growing consensus among the elites that it would be best to implement censitary suffrage, the desire to exclude the working classes did not prove feasible. None of the factions involved were able to 
abstain from appeals to the "lower (threatening) classes". We attempt to explain why this was so. There are several different hypotheses in this regard. One argument is that the early implementation of sufferage was a result of competition between antagonistic factions. However, by the end of the 1820 s, popular mobilization led to social disorder, such as the destruction of the Parian market. This stimulated elite preoccupations. At the beginning of the 1830s, the ruling classes held back on engaging popular classes in electoral struggles. Yet this agreement proved short-lived, with conservatives giving up on the notion of census suffrage and the renewed insistence of liberals, encouraged by electoral triumphs, on maintaining a broad electoral base.

KEYWORDS: Representative Government; Mexico; XIX ${ }^{\text {th }}$ Century; Voting Rights; Electoral ces; Political Mobilization. 
AU-DELÀ DU CONSENSUS RESTRICTIF : LES ÉLECTIONS AU MEXIQUE (1809-1847) José Antonio Aguilar Rivera

Cet article analyse les expériences avec le système représentatif, premièrement dans la NouvelleEspagne, et au Mexique après. Les élections qui ont eu lieu encore sous le domaine espagnol ont réalisé les dynamiques politiques de cette forme de gouvernement, comme la large participation politique. On étudie les élections pendant les premières décennies de l'indépendance, jusqu'au début 
de la guerre avec les États-Unis, et il se trouve que, malgré que pour les années trente du XIX siècle, il y ait eu un consensus croissant entre les élites sur l'envie d'exclure les classes populaires des élections, il a été impossible de maintenir les exclusions censitaires pendant beaucoup de temps. Aucune des factions n'a été capable de s'abstenir du recours aux "classes dangereuses ». Le chapitre essaie de faire comprendre les raisons de cet impossibilité. Il existe plusieurs hypothèses pour expliquer ce modèle. On affirme qu'au début, l'incomplète ouverture de la libération aurait obéi à la concurrence entre des factions antagoniques. Toutefois, à la fin des années 1820, la mobilisation populaire a causé des désordres sociaux, comme la destruction du marché du Parián, ce qui l'a rendue dysfonctionnelle d'après les élites. Vers les années 1830, les classes dirigeantes ont décidé de ne pas utiliser les classes populaires dans les disputes électorales. Cependant, cet accord n'a pas duré et l'on croit que c'est dû au fait que les conservateurs aient abandonné l'idée du suffrage censitaire, et encore les libéraux, qui auraient renouvelé leur insistance à maintenir une large libération, grâce à leurs triomphes électoraux.

MOTS-CLÉS: gouvernement représentatif; Mexique ; XIXè siècle ; droit de vote; pratiques électorales; mobilisation politique. 